\title{
INVENTARISASI TUMBUHAN BERKHASIAT OBAT DI HUTAN KANTUK DESA PAOH BENUA KABUPATEN SINTANG
}

\section{INVENTORY OF MEDICINAL PLANTS IN THE KANTUK FOREST OF PAOH BENUA VILLAGE, SINTANG REGENCY}

\author{
Fathul Yusro $^{1 *}$, Erianto ${ }^{1}$, Gusti Hardiansyah ${ }^{1}$, Yeni Mariani ${ }^{1}$, Aripin ${ }^{2}$, Hendarto ${ }^{3}$ dan \\ Denni Nurdwiansyah ${ }^{4}$ \\ ${ }^{1}$ Fakultas Kehutanan Universitas Tanjungpura, Pontianak, Indonesia \\ ${ }^{2}$ Dinas Kehutanan Provinsi Kalimantan Barat, Pontianak, Indonesia \\ ${ }^{3}$ Kesatuan Pengelolaan Hutan (KPH) Kayong, Kayong Utara, Indonesia \\ ${ }^{4}$ Bentang Kalimantan, Pontianak, Indonesia \\ *Email: fathulyusro@gmail.com
}

Diterima: 21 Agustus 2020. Disetujui: 3 Maret 2021. Dipublikasikan: 3 Maret 2021

\begin{abstract}
Abstrak: Penelitian ini bertujuan untuk menginventarisasi jenis dan potensi tumbuhan berkhasiat obat yang terdapat dihutan Kantuk Desa Paoh Benua Kecamatan Sepaok Kabupaten Sintang. Penelitian ini diawali dengan membuat sebuah klaster berbentuk persegi yang berjarak $100 \mathrm{~m}$, dan disetiap sudut dan bagian tengah klaster terdapat plot berbentuk lingkaran dengan jari-jari 17,8 $\mathrm{m}$. Setiap plot dibuat empat buah subplot bentuk lingkaran yang terdiri dari subplot untuk tingkat semai dengan jari-jari $1 \mathrm{~m}$, pancang berjari-jari $2 \mathrm{~m}$, tiang berjari-jari $5 \mathrm{~m}$ dan pohon berjari-jari 17,8 $\mathrm{m}$. Data jenis tumbuhan di identifikasi nama ilmiahnya dan besarnya potensi tumbuhan di analisis dengan kerapatan (individu/Ha) dan kerapatan relatif (\%). Hasil penelitian menunjukkan bahwa di hutan Kantuk terdapat 34 jenis tumbuhan obat. Jenis tumbuhan yang paling dominan atau memiliki kerapatan dan kerapatan relatif yang tinggi pada tingkat semai (10.500 individu/Ha (52,5\%)), pancang (3.500 individu/Ha $(36,84 \%))$, tiang $(140$ individu/Ha $(58,33 \%))$ dan pohon $(117,28$ individu/Ha $(38,78 \%))$ adalah Alseodaphne sp. Perlindungan terhadap hutan Kantuk dan keanekaragaman jenis tumbuhan obatnya perlu dilakukan melalui peningkatan statusnya menjadi hutan yang bernilai konservasi tinggi (NKT).
\end{abstract}

Kata Kunci: Inventarisasi, tumbuhan obat, hutan Kantuk, Area Penggunaan Lain

\begin{abstract}
This study aims to inventory the species and potential of medicinal plants in the Kantuk forest of Paoh Benua Village, Sepaok District, Sintang Regency. The research begins by making a square-shaped cluster within $100 \mathrm{~m}$; in each corner and center of it, there is a circular plot with a radius of $17.8 \mathrm{~m}$. Each plot is made of four circular sub-plots consisting of a sub-plot for seedlings with a radius ( $\mathrm{r}$ ) of $1 \mathrm{~m}$, stakes with $(\mathrm{r}=2 \mathrm{~m})$, poles of 5 meters, and trees of $17.8 \mathrm{~m}$. Data on plant species were identified by their scientific name and the magnitude of plant potential analyzed by density (individual/ha) and relative density (\%). The results showed that in the Kantuk forest, there were 34 species of medicinal plants. The most dominant plant species or have a high relative density and density at seedling level (10,500 individuals/Ha (52.5\%)), saplings (3,500 individuals/Ha (36.84\%)), poles (140 individuals/Ha (58.33\%)) and trees (117.28 individuals/Ha (38.78\%)) are Alseodaphne sp. Protection on Kantuk forests and the diversity of medicinal plant species must be done through upgrading their status to high conservation value forests (HCVF).
\end{abstract}

Keywords: Inventory, medicinal plants, Kantukforest, non-forest estate

\section{PENDAHULUAN}

Degradasi hutan merupakan problematika yang terus dihadapi oleh bangsa Indonesia setiap tahunnya. Degradasi hutan ini bukan hanya terjadi di kawasan hutan, tetapi juga di Area Penggunaan Lain (APL). Tahun 2017-2018, degradasi bruto hutan di kawasan hutan sebesar 265,7 ribu Ha, sedangkan di APL mencapai 227,7 ribu Ha [1]. Usaha penyelamatan hutan penting dilakukan karena dengan selamatnya hutan maka keanekaragaman hayati yang ada didalamnya juga akan terselamatkan. Salah satu keanekaragaman hayati yang penting bagi kehidupan manusia adalah tumbuhan obat.
Tumbuhan obat bagi masyarakat saat ini menjadi bagian penting dalam usaha meningkatkan taraf kesehatan berbasis pada bahan alami (natural product) [2]. Selain itu juga terdapat kecenderungan dari masyarakat untuk kembali kepada alam (back to nature) [3]. Hal tersebut tentu berdampak pada meningkatnya kebutuhan akan tumbuhan obat dan kondisi tersebut harus didukung dengan ketersediaan yang cukup dari tumbuhan obat, baik yang berasal dari tanaman budidaya maupun tanaman yang tumbuh secara alami/liar dihutan [4]. Identifikasi dan inventarisasi potensi terkait keanekaragaman jenis tumbuhan yang ada disetiap daerah menjadi 
penting untuk dilakukan dalam rangka pemenuhan kebutuhan yang besar akan tumbuhan obat ataupun sebagai usaha pelestarian terhadap jenis-jenis tumbuhan yang sudah dianggap sulit diperoleh (langka).

Keanekaragaman jenis tumbuhan obat di Kalimantan Barat tergolong cukup tinggi, seperti yang dilaporkan oleh Rahman et al. bahwa di hutan Tembawang Keluruhan Beringin Sanggau terdapat 100 jenis tumbuhan obat [5], 93 jenis di Desa Durian Sebatang Kayong Utara [6], 198 jenis di sekitar TWA Bukit Kelam Sintang [7], dan sebanyak 702 jenis tumbuhan obat telah digunakan secara tradisional oleh masyarakat di Kalimantan Barat [8]. Keanekaragaman jenis tumbuhan obat tersebut haruslah dipertahankan, salah satunya dengan tetap menjaga hutan yang berada dekat dengan lingkungan tempat tinggal masyarakat dalam hal ini adalah hutan yang berada di APL.

Salah satu daerah di Kalimantan Barat yang masyarakatnya secara swadaya berupaya melakukan penyelamatan hutan khususnya di APL adalah Kabupaten Sintang. Beberapa daerah yang diusulkan oleh masyarakat untuk dilindungi telah disetujui dan ditetapkan oleh Bupati Kabupaten Sintang sebagai hutan Budaya seperti hutan Semilas, Mersibung dan Sebasai maupun hutan Tutupan seperti hutan tawang Selubang. Beberapa hutan lain juga telah diusulkan untuk dilindungi seperti hutan Tawang Serimbak di Desa Ensaid Panjang dan telah terdata terdapat 49 jenis tumbuhan obat [4], ataupun hutan Kantuk di Desa Paoh Benua dimana hutan ini memiliki vegetasi yang masih sangat baik dan dimanfaatkan masyarakat sebagai sumber hasil hutan bukan kayu (HHBK), namun hingga saat ini belum diketahui jenis-jenis tumbuhan obat apa saja yang terdapat di hutan Kantuk, dan seberapa besar pula potensinya. Penelitian ini bertujuan untuk menginventarisasi jenis dan potensi tumbuhan berkhasiat obat yang terdapat dihutan Kantuk Desa Paoh Benua Kecamatan Sepaok Kabupaten Sintang.

\section{METODE PENELITIAN}

Penelitian ini dilaksanakan di hutan Kantuk Desa Paoh Benua Kecamatan Sepaok Kabupaten Sintang (Gambar 1) pada bulan April 2019. Peralatan yang digunakan berupa GPS, meteran, dan phi band. Penelitian ini diawali dengan membuat sebuah klaster berbentuk persegi yang berjarak $100 \mathrm{~m}$, dan disetiap sudut dan bagian tengah klaster terdapat plot berbentuk lingkaran dengan jari-jari $17,8 \mathrm{~m}$. Selanjutnya pada setiap plot dibuat empat buah subplot berbentuk lingkaran yang terdiri dari subplot untuk tingkat semai dengan jari-jari $1 \mathrm{~m}$, pancang berjari-jari $2 \mathrm{~m}$, tiang berjari-jari $5 \mathrm{~m}$ dan pohon berjari-jari 17,8 m (Gambar 2) [9].

Data jenis tumbuhan pada setiap tingkat pertumbuhan yang diperoleh selanjutnya dilakukan identifikasi nama ilmiah, dan potensi manfaat tumbuhan obatnya berdasarkan kajian pustaka [4]. Besarnya potensi tumbuhan yang terdapat di hutan
Kantuk selanjutnya dilakukan analisis berupa kerapatan (individu/Ha) dan kerapatan relatif (\%) dengan persamaan [9]:

$$
\begin{aligned}
& \text { Kerapatan }(K)=\frac{\text { Jumlah Individu suatu jenis }}{\text { Luas seluruh unit contoh }} \\
& \text { Kerapatan Relatif }(\mathrm{KR})=\frac{\text { Kerapatan suatu jenis }}{\text { Kerapatan seluruh jenis }} \times 100 \%
\end{aligned}
$$

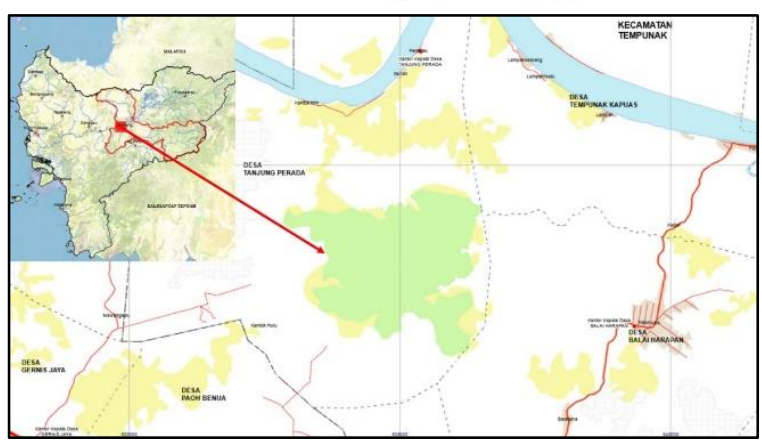

Gambar 1. Lokasi penelitian di hutan Kantuk Desa Paoh Benua Kabupaten Sintang

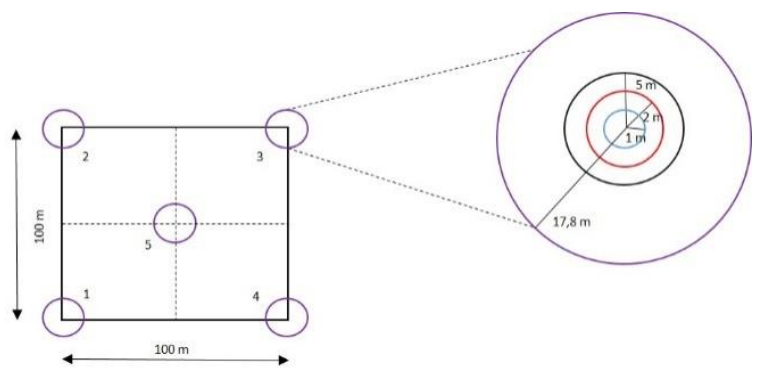

Gambar 2. Desain klaster penelitian

HASIL DAN PEMBAHASAN

\section{Kondisi vegetasi dan jenis-jenis tumbuhan obat di hutan Kantuk}

Hutan Kantuk yang berlokasi di Desa Paoh Benua Kecamatan Sepaok Kabupaten Sintang termasuk dalam kategori hutan sekunder tua, memiliki vegetasi yang tergolong masih sangat baik dan beberapa pohon berdiameter besar masih banyak dijumpai di hutan ini (Gambar 3). Hutan ini secara swadaya dijaga dan dikelola oleh masyarakat setempat. Usaha untuk melindungi hutan ini telah dilakukan oleh masyarakat dalam bentuk pengajuan ijin perlindungan kepada Bupati Sintang, namun hingga saat ini status hutan tersebut belum dikeluarkan/disetujui oleh Bupati.

Hutan Kantuk tergolong kedalam hutan rawa gambut, dimana pada musim hujan, kondisi lantai hutannya digenangi oleh air sehingga hutan ini berpotensi untuk digunakan sebagai daerah resapan air. Hutan ini juga menjadi tempat tinggal/ persinggahan beberapa jenis fauna khususnya burung seperti Megalaima rafflesii, M. australis dan Arachonthera longirosta. Beberapa lokasi terdapat bekas tebangan, namun sudah lama ditinggalkan. Hutan ini dimanfaatkan oleh masyarakat sebagai tempat untuk mengambil hasil 
hutan bukan kayu (HHBK) seperti rotan, madu, tanaman hias dan tumbuhan obat.
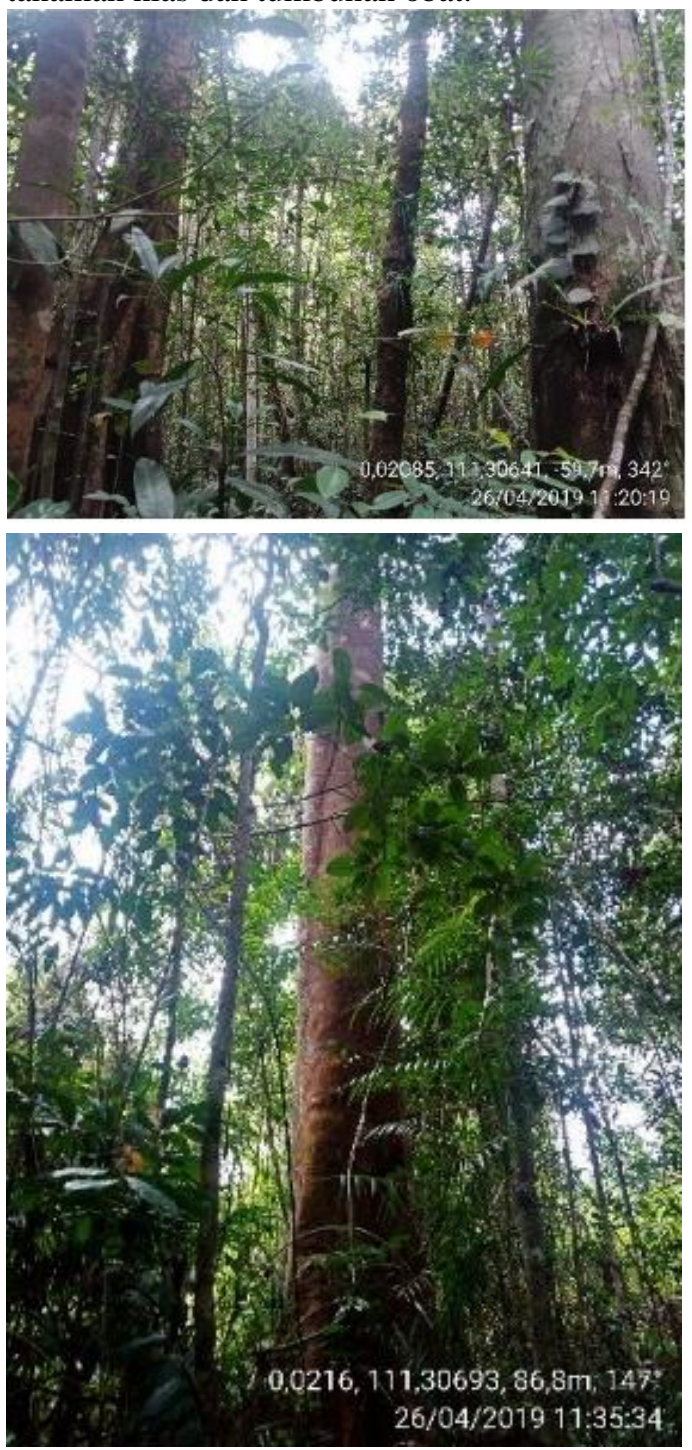

Gambar 3. Kondisi vegetasi Hutan Kantuk

Hasil inventarisasi yang dilakukan menunjukkan bahwa di hutan Kantuk terdapat 34 spesies tumbuhan yang berpotensi sebagai obat yang terdistribusi dalam 29 genus dan 25 famili (Tabel 1). Jika dibandingkan dengan hutan di APL lainnya dikabupaten Sintang seperti hutan Tawang Serimbak yang terdapat 49 jenis tumbuhan obat [4] maka jenis tumbuhan obat yang ditemukan ini tergolong lebih sedikit. Namun jika dibandingkan dengan beberapa daerah lain di Indonesia seperti di daerah Hutan Lindung Gunung Pakuan Kuningan terdapat 32 jenis tumbuhan obat [11] dan di Hutan Turgo Sleman terdapat 33 jenis [12] maka tumbuhan obat yang terdapat di hutan Kantuk ini tergolong sedikit lebih banyak.

Setiap hutan memiliki karakteristiknya tersendiri dan hal tersebut berdampak pada terjadinya keragaman jenis tumbuhan obat yang ditemukan disetiap tipe hutan. Adanya keragaman jenis tumbuhan obat yang ditemukan di hutan Kantuk ini tentu menambah khasanah jenis-jenis tumbuhan obat yang ada di Kalimantan Barat dan khususnya pada Kabupaten Sintang.

Jenis-jenis tanaman dari kelompok famili Dipterocarpaceae adalah tanaman dengan persentase terbanyak yang dijumpai di hutan Kantuk (8, 82\%), di ikuti oleh beberapa famili dengan persentase yang sama yaitu Trymelaceae, Stemonuraceae, Rubiaceae, Myrtaceae, Fabaceae, Euphorbiaceae, dan Burseraceae (5,88\%), sedangkan beberapa jenis lainnya tergolong memiliki persentase yang lebih rendah (Gambar 4). Hutan Kantuk termasuk kedalam hutan rawa gambut, dan beberapa hutan di Indonesia yang tergolong kedalam hutan rawa gambut di dominasi oleh famili Dipterocarpaceae seperti hutan lindung Danau Sentarum Kapuas Hulu [13] dan hutan di Semenanjung Kampar Riau [10]. Beberapa laporan menunjukkan bahwa jenis-jenis tumbuhan dari famili Dipterocarpaceae banyak teridentifikasi berkhasiat sebagai obat $[14 ; 4]$.

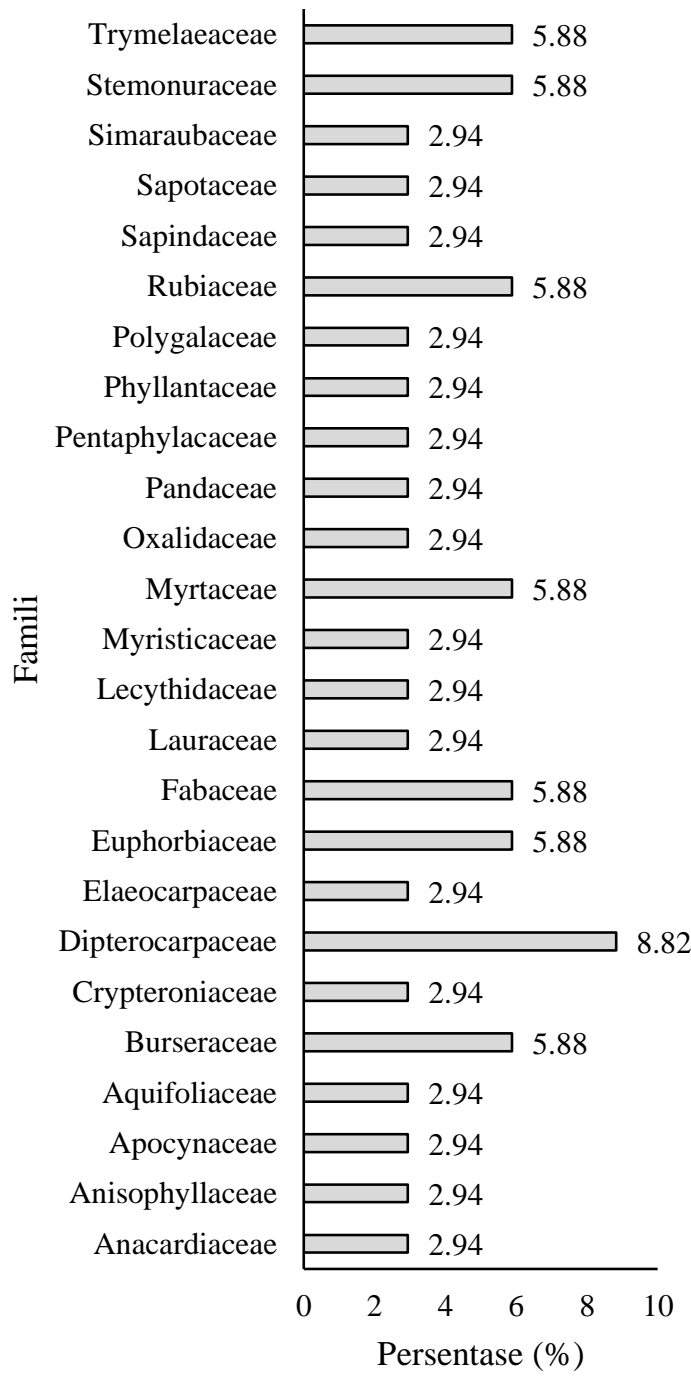

Gambar 4. Famili tumbuhan obat yang ditemukan di hutan Kantuk 
Tabel 1. Jenis-jenis tumbuhan berpotensi sebagai obat pada beberapa tingkatan pertumbuhan di Hutan Kantuk

\begin{tabular}{|c|c|c|c|c|c|c|}
\hline \multirow[t]{2}{*}{ No. } & \multirow[t]{2}{*}{ Nama Latin } & \multirow[t]{2}{*}{ Famili } & \multicolumn{4}{|c|}{$\begin{array}{c}\text { Tingkat } \\
\text { Pertumbuhan* } \\
\end{array}$} \\
\hline & & & $\mathbf{S}$ & Pc & $\mathbf{T}$ & $\mathbf{P h}$ \\
\hline 1 & Alseodaphne sp & Lauraceae & $\mathrm{V}$ & $\mathrm{V}$ & $\mathrm{V}$ & $\mathrm{V}$ \\
\hline 2 & Archidendron borneense (Benth.) Nielsen & Fabaceae & & $\vee$ & & \\
\hline 3 & Baccaurea bracteata Mull. & Phyllantaceae & & $\vee$ & & $\vee$ \\
\hline 4 & Barringtonia macrostachya (Jack) Kurz & Lecythidaceae & & $\vee$ & & \\
\hline 5 & Cantleya corniculata (Becc.) R.A.Howard & Stemonuraceae & $\vee$ & $\vee$ & & \\
\hline 6 & Combretocarpus rotundatus (Miq.) Danser & Anisophyllaceae & & & & $\vee$ \\
\hline 7 & Copaifera palustris (Syimngton) De Wit & Fabaceae & & & & $\vee$ \\
\hline 8 & Dacryodes incurvata (Engl.) H.J.Lam & Burseraceae & & & V & \\
\hline 9 & Dacryodes rugosa (Blume) H.J.Lam & Burseraceae & & $\vee$ & & \\
\hline 10 & Dactylocladus stenostactys Oliver & Crypteroniaceae & & & & $\vee$ \\
\hline 11 & Dryobalanops oblongifolia Dyer. & Dipterocarpaceae & $\vee$ & $\vee$ & & $\vee$ \\
\hline 12 & Dyera lowii Hook.f & Apocynaceae & & & & $\vee$ \\
\hline 13 & Elaeocarpus masretsii King & Elaeocarpaceae & & $\vee$ & & \\
\hline 14 & Eurya sp & Pentaphylacaceae & $\vee$ & & & \\
\hline 15 & Galearia fulva (Tul.) Miq. & Pandaceae & & $\vee$ & & \\
\hline 16 & Gonystylus bancanus & Trymelaeaceae & & $\vee$ & & $\vee$ \\
\hline 17 & Gonystylus maingayi Hook.f. & Trymelaeaceae & & $\vee$ & & \\
\hline 18 & Ilex cymosa Blume & Aquifoliaceae & & $\vee$ & & \\
\hline 19 & Ixora $s p$ & Rubiaceae & $\vee$ & & & \\
\hline 20 & Knema laterica Elmer & Myristicaceae & & $\vee$ & & \\
\hline 21 & Macaranga caladiifolia Becc. & Euphorbiaceae & & $\vee$ & V & \\
\hline 22 & Macaranga pruinosa (Miq.) Mull & Euphorbiaceae & & & & $\vee$ \\
\hline 23 & Madhuca motleyana (de Vriese) J.T. Macbr & Sapotaceae & & $\vee$ & & \\
\hline 24 & Mangifera parvifolia Boerl. \& Koord. & Anacardiaceae & $\vee$ & $\vee$ & V & $\vee$ \\
\hline 25 & Nephelium maingayi Hiern & Sapindaceae & $\vee$ & $\vee$ & & \\
\hline 26 & Quassia borneensis Noot & Simaraubaceae & & $\vee$ & & \\
\hline 27 & Sarcotheca diversifolia (Miq.) Hallier.f. & Oxalidaceae & $\vee$ & $\vee$ & & \\
\hline 28 & Shorea placycarpa $\mathrm{F}$. Heim & Dipterocarpaceae & & $\vee$ & & \\
\hline 29 & Shorea uliginosa Faxw. & Dipterocarpaceae & & $\vee$ & $\vee$ & \\
\hline 30 & Stemonurus secundiflorus Blume & Stemonuraceae & & $\vee$ & & \\
\hline 31 & Syzygium laniatum (DC.) Merr.\& J.Parn. & Myrtaceae & $\vee$ & $\vee$ & V & $\vee$ \\
\hline 32 & Syzygium $s p$ & Myrtaceae & & $\vee$ & & \\
\hline 33 & Timonius sp & Rubiaceae & $\vee$ & & & \\
\hline 34 & Xantophyllum amoenum Chadat & Polygalaceae & $\vee$ & $\vee$ & & \\
\hline
\end{tabular}

Keterangan: $* \mathrm{~S}=$ semai; $\mathrm{Pc}=$ pancang; $\mathrm{T}=$ tiang; $\mathrm{Ph}=$ pohon

\section{Potensi dan manfaat tumbuhan obat berdasarkan tingkat pertumbuhan}

Tumbuhan obat yang ditemukan dihutan Kantuk terdistribusi pada tingkat semai, pancang, tiang dan pohon. Jumlah spesies yang ditemukan pada masing-masing tingkatan tersebut sangat beragam, namun yang tertinggi terdapat pada tingkat pancang, diikuti semai, pohon dan tiang (Gambar 5). Tingginya jumlah spesies pada tingkat pancang dan semai sangatlah penting, karena pada masa yang akan datang tingkatan pertumbuhan tersebutlah yang akan menjadi pohon induk yang tentunya keanekaragaman jenis tumbuhan obat di hutan Kantuk dapat dipertahankan jika tidak terjadi eksploitasi secara berlebihan terhadap jenis-jenis tumbuhan obat tersebut.

Jenis-jenis tumbuhan obat khususnya pada tingkat pohon dan tiang yang ditemukan dalam jumlah sedikit, tentu harus dipertahankan agar jangan sampai hilang akibat dari eksploitasi untuk diambil kayunya sebagai bahan pertukangan ataupun kepentingan lainnya. Oleh karena itu, kesadaran masyarakat untuk tetap mempertahankan kondisi hutan yang sudah baik ini haruslah didukung secara penuh oleh berbagai pihak, karena dengan selamatnya hutan ini maka keanekaragaman jenis tumbuhan obat yang ada dihutan Kantuk pada berbagai tingkat pertumbuhan dapat dipertahankan untuk generasi dimasa yang akan datang.

Besarnya potensi tumbuhan obat dari berbagai jenis yang terdapat pada masing-masing tingkat pertumbuhan dapat dianalisa dari besarnya kerapatan dan kerapatan relatif, dimana kerapatan menunjukkan banyaknya jumlah individu yang terdapat dalam satu hektar hutan [9]. Jenis-jenis tumbuhan obat yang ditemukan pada masingmasing tingkatan ada yang sama, namun ada juga yang berbeda, sehingga tanaman yang tersedia pada 
lebih dari satu tingkatan pertumbuhan tentu memiliki potensi yang besar untuk dikembangkan, sedangkan tumbuhan yang memiliki potensi yang kecil perlu untuk dikonservasi.

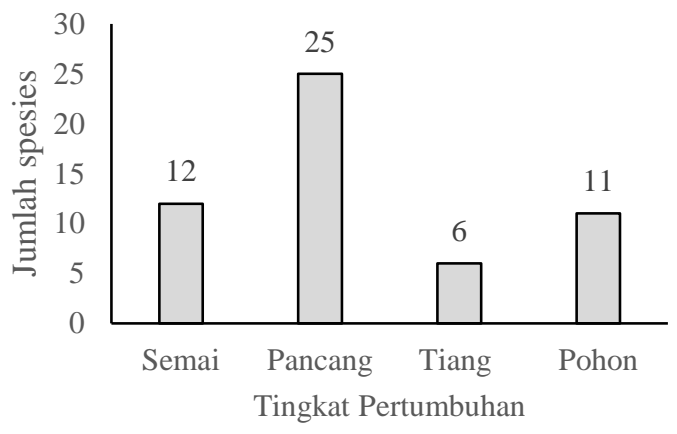

Gambar 5. Jumlah spesies tumbuhan obat dihutan kantuk berdasarkan pada tingkat pertumbuhan

Jenis-jenis tumbuhan obat pada tingkat semai

Jumlah spesies yang ditemukan pada tingkat semai sebanyak 12 spesies dengan besarnya kerapatan 20.000 individu/Ha. Kerapatan dan kerapatan relatif tertinggi terdapat pada tanaman Alseodaphne $s p$ dengan nilai kerapatan sebesar 10.500 individu/Ha (52,5\%), X. amoenum 2.000 individu/Ha (10\%), dan I. cymosa 1.500 individu/Ha $(7,5 \%)$, sedangkan jenis-jenis yang lainnya memiliki kerapatan dan kerapatan relatif yang lebih rendah
(Gambar 6). Jenis-jenis tumbuhan obat yang memiliki potensi besar yang ditunjukkan dengan besarnya jumlah individu/Ha maka tanaman tersebut dapat menjadi bibit untuk pengembangan tanaman tersebut diluar hutan ataupun untuk keberlangsungan jenis tumbuhan obat tersebut di hutan Kantuk.

Beberapa manfaat ataupun komponen senyawa dari tumbuhan obat yang ditemukan pada tingkat semai ini antara lain: Alseodaphne sp dimana genus ini diketahui mengandung beberapa komponen senyawa bioaktif seperti aporphin, lakton, furanon, phenanthren, bisbenzylisoquinolin alkaloid dan morphinandienon sehingga sangat potensial sebagai bahan obat-obatan [15], $X$. amoenum diketahui berkhasiat sebagai obat penyakit kulit maupun untuk perawatan rambut [16], I. cymosa untuk obat laksatif [17] dan obat kudis [18], D. oblongifolia untuk obat sakit malaria [19], $S$. diversifolia yang berpotensi sebagai antioksidan [20] dan S. laniatum untuk pengobatan diabetes ataupun inflamasi [21]. Beragamnya khasiat dari tanaman tingkat semai yang ditemukan di hutan Kantuk maka keberadaan tanaman tersebut harus dipertahankan agar dapat menjadi tanaman dengan tingkat pertumbuhan yang lebih tinggi dalam hal ini adalah pancang, tiang dan pohon.

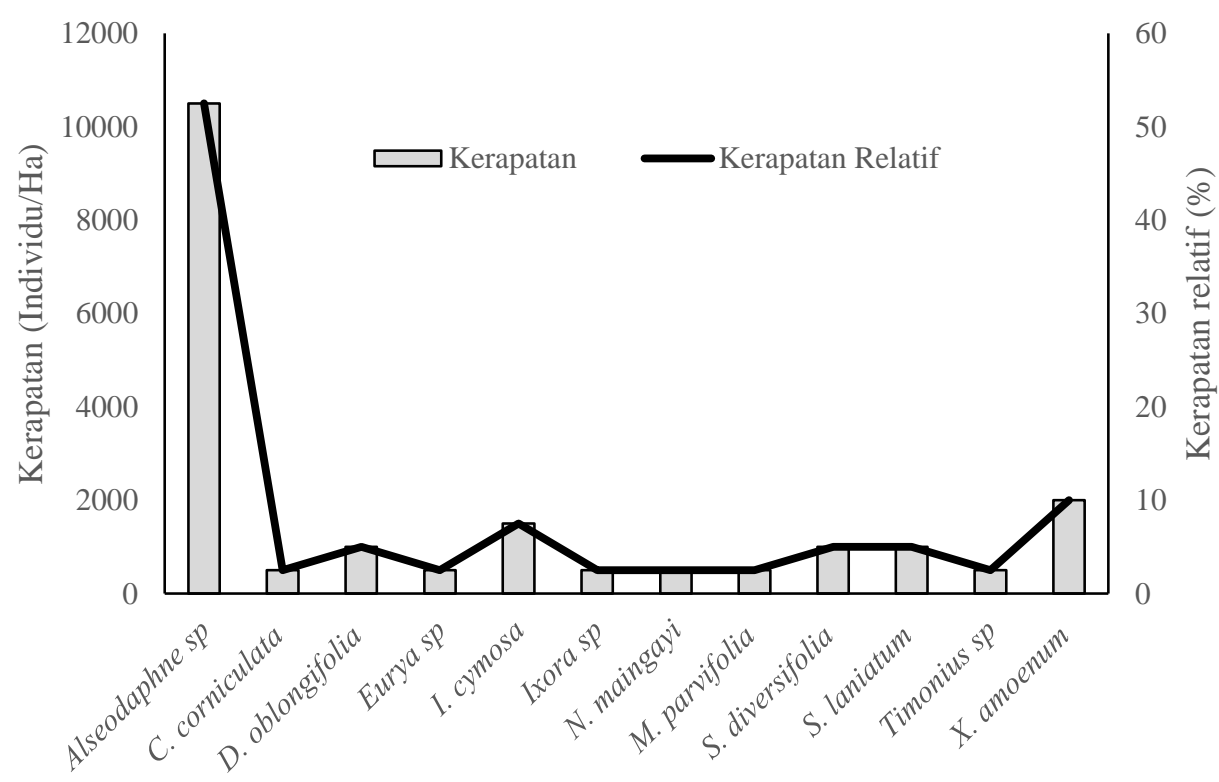

Jenis tumbuhan

Gambar 6. Kerapatan dan kerapatan relatif tumbuhan obat pada tingkat semai 


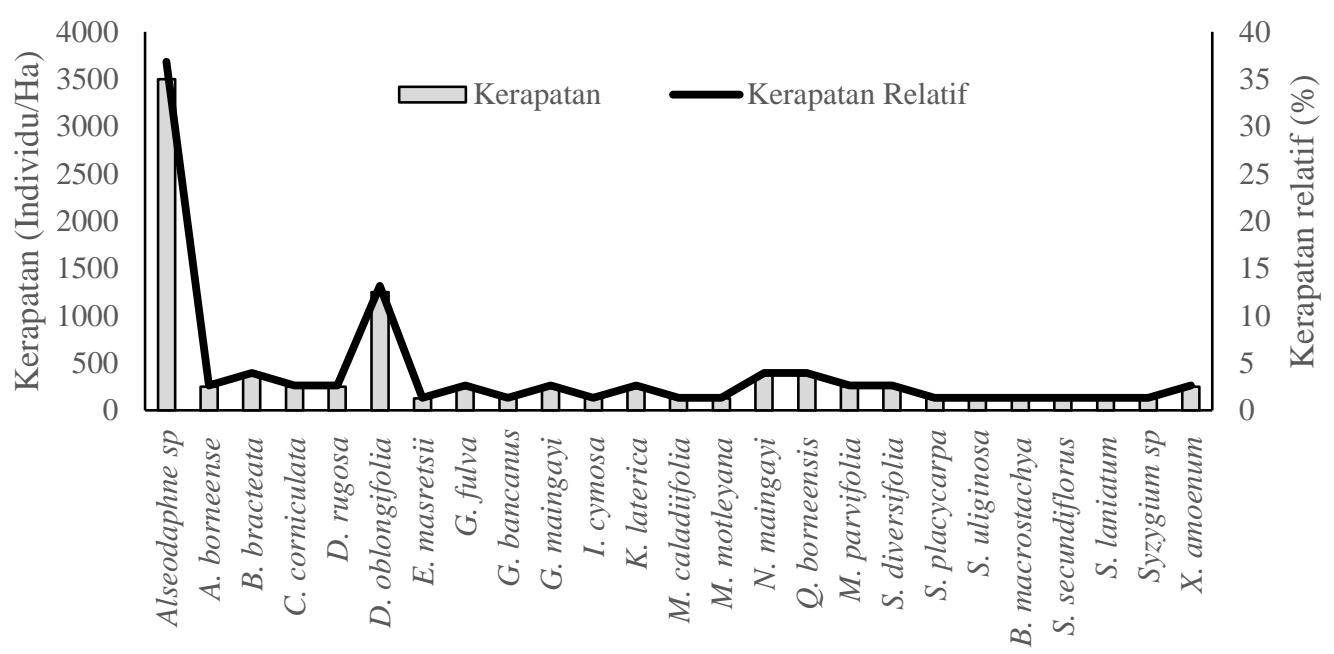

Jenis tumbuhan

Gambar 7. Kerapatan dan kerapatan relatif tumbuhan obat pada tingkat pancang

\section{Jenis-jenis tumbuhan obat pada tingkat pancang}

Jumlah spesies pada tingkat pancang yang diperoleh dalam penelitian ini sebanyak 25 species dengan kerapatan 9.500 individu/Ha. Jumlah species pada tingkat pancang lebih banyak jika dibandingkan dengan tingkat semai. Spesies dengan kerapatan dan kerapatan tertinggi adalah Alseodaphne sp 3.500 individu/Ha $(36,84 \%)$, D. oblongifolia 1.250 individu/Ha $(13,16 \%)$, dan beberapa spesies memiliki kerapatan yang sama sebesar 375 individu/Ha (3,95\%) seperti $B$. bracteata, N. maingayi, Q. borneensis (Gambar 7). Adapun jenis-jenis yang lain tergolong memiliki kerapatan yang lebih rendah. Spesies tertinggi pada tingkat pancang juga tertinggi pada tingkat semai. Hal ini berarti bahwa potensi tanaman Alseodaphne $s p$ di hutan Kantuk cukup besar dan diharapkan tanaman ini dapat terus berkembang sampai pada tingkat tiang dan pohon.
Beberapa jenis tanaman yang terdapat pada tingkat pancang juga terdapat pada tingkat semai. Adapun khasiat dari beberapa tanaman yang ditemukan pada tingkatan pancang antara lain $B$. bracteata untuk obat panas dalam dan kurap [22], $N$. maingayi memiliki komponen bioaktif berupa saponin dan potensial sebagai anti kanker [23], $Q$. borneensis untuk antiproliferatif, antioksidan dan anti inflamasi [24], D. rugosa mengandung senyawa bioaktif berupa fenol, alkaloid, tanin dan steroid [25], E. mastersii sangat potensial untuk anti kanker [26] dan Syzygium sp untuk mengatasi penyakit arthritis dan outoimun [27]. Beragamnya khasiat yang dimiliki oleh tanaman-tanaman dari tingkat pancang tersebut membuka peluang untuk diteliti lebih lanjut sehingga dapat menjadi produk obatobatan baik dalam bentuk herbal maupun sudah dalam bentuk fitofarmaka.

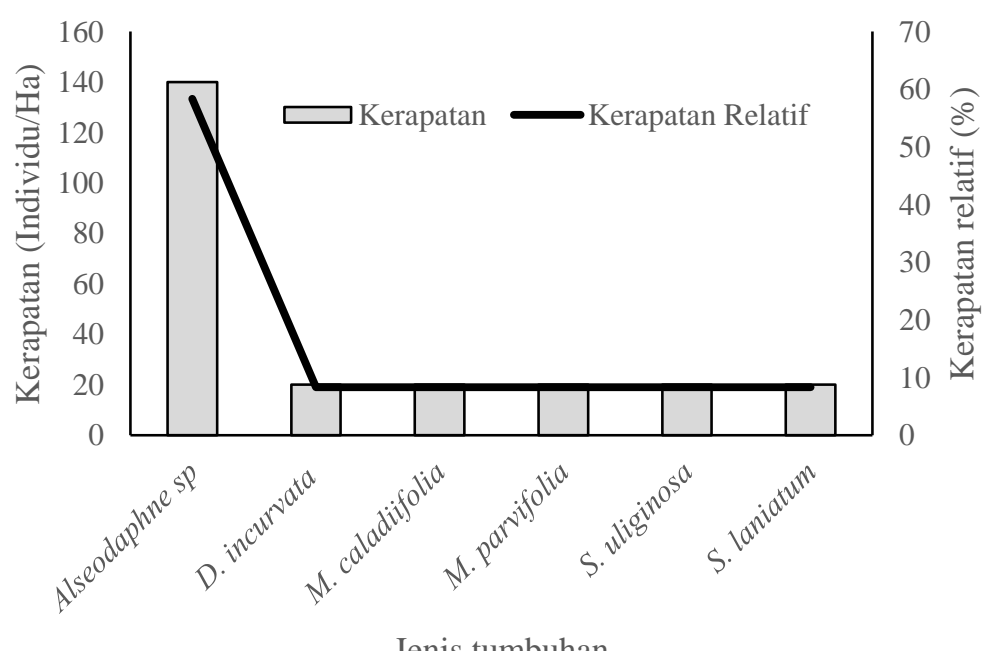

Gambar 8. Kerapatan dan kerapatan relatif tumbuhan obat pada tingkat tiang 


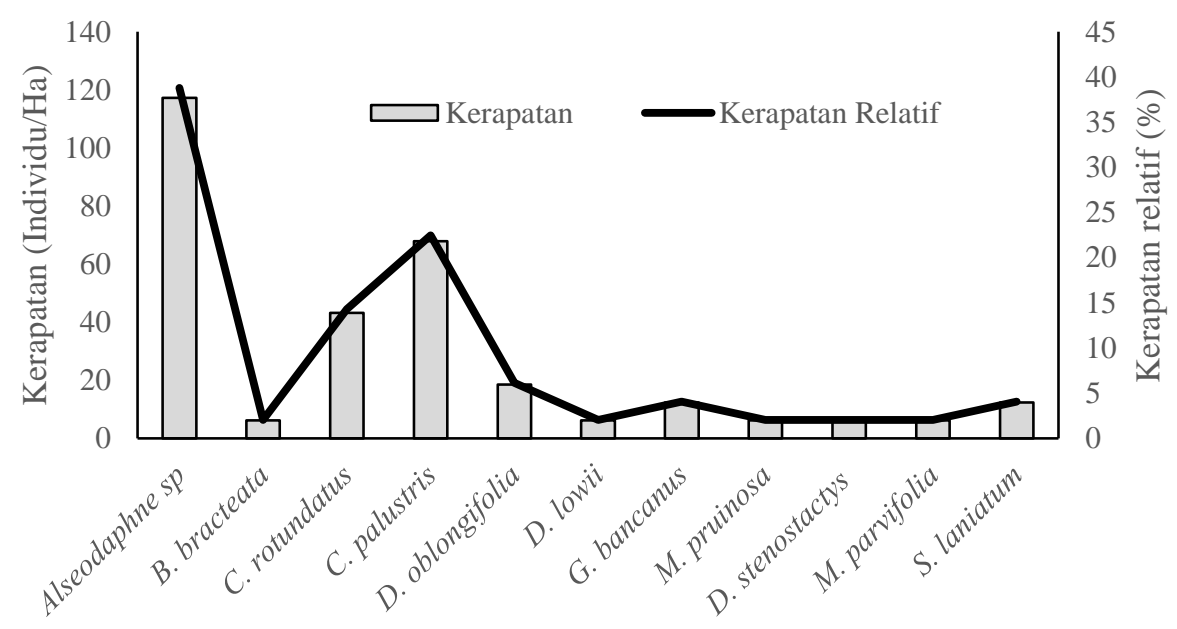

Jenis tumbuhan

Gambar 9. Kerapatan dan kerapatan relatif tumbuhan obat pada tingkat pohon

Jenis-jenis tumbuhan obat pada tingkat tiang

Jumlah spesies tumbuhan yang tergolong

pada tingkat tiang sebanyak 6 spesies dengan kerapatan 240 individu/Ha. Jumlah species pada tingkat tiang lebih sedikit jika dibandingkan dengan tingkat semai dan pancang. Spesies dengan kerapatan dan kerapatan relatif tertinggi adalah Alseodaphne sp 140 individu/Ha $\quad(58,33 \%)$, sedangkan spesies lainnya memiliki nilai yang sama yaitu 20 individu/Ha (8,33\%). Spesies dengan kerapatan tertinggi yang terdapat pada tingkat tiang, juga terdapat pada tingkat semai dan pancang. Hal ini berarti populasi tanaman Alseodaphne sp cukup melimpah di hutan Kantuk dan ini membuka peluang untuk memanfaatkan dan mengembangkannya menjadi produk-produk kesehatan alami. Namun, jika dilihat dari minimnya jumlah spesies yang terdapat pada tingkat tiang ini mengindikasikan bahwa pada masa lalu telah terjadi eksploitasi di hutan Kantuk khususnya pada tingkat pohon dan tiang sehingga spesies tingkat pancang yang ada saat ini hanyalah spesies yang tersisa baik pada tingkat semai ataupun pancang pada masa lalu dan telah berkembang menjadi tanaman tingkat tiang pada saat ini.

Beberapa jenis tanaman yang terdapat pada tingkat tiang juga terdapat pada tingkat semai dan pancang, sehingga secara manfaat menjadi sama. Adapun tanaman lain yang tidak terdapat pada tingkat semai dan pancang adalah $S$. uliginosa dimana tanaman ini sangat berpotensi untuk digunakan sebagai antioksidan maupun anti kanker [14]. Adaya khasiat dan potensi yang dimiliki oleh tanaman dari tingkat tiang ini perlu untuk dipertahankan dan ditingkatkan kedepannya agar jangan sampai spesies tanaman tingkat tiang ini hilang akibat dari eksploitasi kayunya ataupun karena konversi hutan menjadi lahan pertanian/perkebunan.

Jenis-jenis tumbuhan obat pada tingkat pohon Jumlah spesies pada tingkat pohon dalam penelitian ini diperoleh 11 species dengan kerapatan 302,47 individu/Ha. Jumlah species pada tingkat pohon lebih banyak jika dibandingkan dengan tingkat tiang, namun lebih sedikit jika dibandingkan dengan tingkat semai dan pancang. Spesies dengan kerapatan dan kerapatan relatif tertinggi adalah Alseodaphne sp 117,28 individu/Ha $(38,78 \%)$, diikuti oleh $C$. palustris 67,9 individu/ $\mathrm{Ha}(22,45 \%)$, C. rotundatus 43,21 individu/Ha $(14,29 \%)$, dan $D$. oblongifolia 18,25 individu/Ha (6,12\%), sedangkan jenis lainnya memiliki kerapatan dan kerapatan relatif yang lebih rendah (Gambar 9).

Beberapa manfaat tumbuhan pada tingkat pohon antara lain Genus Copaifera diketahui berfungsi sebagai anti inflamasi maupun untuk bahan kontrasepsi [28] dan D. lowii untuk bahan produksi kondom [29]. Tumbuhan pada tingkat pohon ini perlu dijaga dari kegiatan pembalakan karena pohon merupakan cikal bakal dari tegakan dibawahnya karena dari pohon inilah akan muncul pohon-pohon induk yang menjadi sumber benih bagi tanaman yang akan meregenerasi tumbuhan yang ada di hutan Kantuk.

Potensi tumbuhan obat yang dimiliki oleh hutan Kantuk masih cukup besar dan hal tersebut mencerminkan keadaan hutannya saat ini dimana kondisinya masih sangat baik, dan ini haruslah dipertahankan. Usaha yang dilakukan oleh masyarakat untuk menyelamatkan hutan perlu diapresiasi dan kedepannya diharapkan hutan ini dapat ditingkatkan statusnya menjadi hutan yang dilindungi ataupun menjadi hutan yang bernilai konservasi tinggi. 


\section{KESIMPULAN}

Hutan Kantuk memiliki keanekaragaman jenis tumbuhan obat yang cukup tinggi. Sebanyak 34 jenis tumbuhan obat yang teridentifikasi berkhasiat untuk beragam penyakit seperti kanker, antioksidan, anti inflamasi dan anti diabetes. Jenis tumbuhan yang paling dominan atau memiliki kerapatan tinggi pada tingkat semai, pancang dan tiang adalah Alseodaphne sp. Upaya pemanfaatan dan pengembangan jenis-jenis tumbuhan obat yang memiliki potensi besar perlu dilakukan dan jenisjenis tumbuhan obat yang potensinya tidak terlalu besar perlu dilakukan konservasi. Perlindungan terhadap hutan Kantuk perlu dilakukan melalui peningkatan statusnya menjadi hutan yang bernilai konservasi tinggi.

\section{UCAPAN TERIMA KASIH}

Terima kasih diucapkan kepada UNDP atas bantuan dana penelitiannya, Project KALFOR, KLHK, PemKab Sintang, KPH Sintang Utara dan Timur, Dinas Kehutanan Provinsi KalBar, Kepala Desa Paoh Benua dan masyarakat yang telah membantu kelancaran penelitian ini.

\section{DAFTAR PUSTAKA}

[1]. Kementerian Lingkungan Hidup dan Kehutanan (2019). Deforestasi Indonesia Tahun 2017-2018. Direkorat Inventarisasi dan Pemantauan Sumber Daya Hutan. Direktorat Jenderal Planologi Kehutanan dan Tata Lingkungan. Kementerian Lingkungan Hidup dan Kehutanan. Jakarta.

[2]. Ani, N., Rohyani, I. S., \& Ustadz, M. (2018). Pengetahuan Masyarakat tentang Jenis Tumbuhan Obat di Kawasan Taman Wisata Alam Madapangga Sumbawa. J. Pijar MIPA, 13(2), 160-166. https://doi.org/10.29303/ jpm.v13i2.751

[3]. Mayangsari, A., Indriyanto, Bintoro, A., \& Surnayanti. (2019). Identification of Medicinal Plants in The Area of KPPH Farmer at Talang Mulya on Wan Abdul Rachman Great Forest Park. Jurnal Sylva Lestari, 7(1), 1-9. https://doi.org/10.23960/js1171-9

[4]. Yusro, F., Hardiansyah, G., Erianto, Mariani, Y., Aripin, Hendarto, \& Nurdwiansyah, D. (2020). Biodiversity of Medicinal Plants in Tawang Serimbak Forest, Ensaid Panjang Village, Sintang Regency. Jurnal Biologi Tropis, 20(2), 245-255. https://doi.org/10.29303/jbt.v20i2.1933

[5]. Rahman, K., Wardenaar, E., \& Mariani, Y. (2019). Identifikasi Jenis dan Pemanfaatan Tumbuhan Obat di Hutan Tembawang oleh Masyarakat Kelurahan Beringin Kecamatan Kapuas Kabupaten Sanggau. Jurnal Hutan Lestari, 7(1), 44-55.

[6]. Wulandara, Dine, F., \& Linda, R. (2018). Etnobotani Tumbuhan Obat Suku Melayu
Desa Durian Sebatang Kecamatan Seponti Kabupaten Kayong Utara. Protobiont, 7(3), 36-46.

[7]. Yusro, F., Pranaka, R. N., Budiastutik, I., \& Mariani, Y. (2020). Pemanfaatan Tumbuhan Obat oleh Masyarakat Sekitar Taman Wisata Alam (TWA) Bukit Kelam, Kabupaten Sintang, Kalimantan Barat. Jurnal Sylva Lestari, 8(2), 255-272. https://doi.org/http://dx.doi.org/10.23960/jsl2 8255-272

[8]. Yusro, F., Mariani, Y., Wardenaar, E., \& Yanieta Arbiastutie. (2020). Database Tumbuhan Obat Tradisional Kalimantan Barat (H. A. Oramahi, Ed.). CV Mitra Natawana, Yogyakarta

[9]. Perdirjen P.1/PKTL/IPSDH/PLA.1/1/2017 (2017). Petunjuk Teknis Inventarisasi Hutan pada Kesatuan Pengelolaan Hutan Lindung (KPHL) dan Kesatuan Pengelolaan Hutan Produksi (KPHP). Direktur Jendral Planologi Kehutanan dan Tata Lingkungan. Jakarta

[10]. Ripin, Astiani, D., \& Burhanuddin. (2017). Jenis-jenis Pohon Penyusun Vegetasi Hutan Rawa Gambut di Semenanjung Kampar Kecamatan Teluk Meranti Provinsi Riau. Jurnal Hutan Lestari, 5(3), 807-813.

[11]. Herlina, N., Nurlaila, A., \& Sandria, I. (2016). Keanekaragaman Dan Pemanfaatan Jenis Tumbuhan Obat Gunung Pakuan Kabupaten Kuningan Provinsi Jawa Barat. Wanaraksa, 10(1), 25-30.

[12]. Mukti, L. P. D., Sudarsono, \& Sulistyono. (2016). Keanekaragaman Jenis Tumbuhan Obat Dan Pemanfaatannya Di Hutan Turgo, Purwobinangun, Pakem, Sleman, Yogyakarta. Jurnal Biologi, 5(5), 9-19.

[13]. Randi, A., Manurung, T. F., \& Siahaan, S. (2014). Identifikasi Jenis-jenis Pohon Penyusun Vegetasi Gambut Taman Nasional Danau Sentarum Kabupaten Kapuas Hulu. Jurnal Hutan Lestari, 2(1), 66-73.

[14]. Syahri, J., Rullah, K., Hilma, R., \& Saputra, D. (2017). Hydroxydammarenone-II dari Kulit Batang Shorea teysmanniana Dier. The 2nd International Conference of the Indonesian Chemical Society 2013, (Oktober), 138-144.

[15]. Thakur, B. K., Anthwal, A., Rawat, D. S., Rawat, B., Rashmi, \& Rawat, M. (2012). A Review on Genus Alseodaphne: Phytochemistry and Pharmacology A Review on Genus Alseodaphne: Phytochemistry and Pharmacology. Organic Chemistry, 9(4), 433445.

https://doi.org/10.2174/157019312804699429

[16]. Muhammad, N., Uddin, N., Khan, M. K. U., Mengjun, L., Xuan, Z., Ali, N., \& Liu, Z. (2020). Ethnomedicinal and Cultural uses of Ziziphus Species in Flora of Malakand Division KP, Pakistan. J. Sci. Res., 10(1), 1-7. 
https://doi.org/10.3923/sjsres.2020.1.7

[17]. Carag, H., \& Buot Jr, I. E. (2017). A checklist of the Orders and Families of Medicinal Plants in the Philippines. Sylvatrop, The Technical Journal of Philippine Ecosystems and Natural Resources, 27(1\&2), 39-83.

[18]. Wardani, M. (2008). Keragaman Potensi Tumbuhan Berguna Di Cagar Alam Mandor, Kalimantan Barat. Jurnal Penelitian Hutan Dan Konservasi Alam, 5(3), 251-266. https://doi.org/10.20886/jphka.2008.5.3.251266

[19]. Indriani (2016). Metabolit Sekunder dari Kulit Batang Tumbuhan Dryobalanops oblongifolia Dyer. Disertasi. Universitas Airlangga

[20]. Wahyuni, R., Safwan, M., \& Nurjani. (2013). Karakterisasi Morfologi dan Habitat Asam Kalimbawan (Sarcotheca diversifolia (Miq) Hallier F). Jurnal Sains Mahasiswa Pertanian, 2(2), 1-8. https://doi.org/10.1007/978-94-0074053-2_14

[21]. Zarate-manicad, M. C. (2016). Phytochemical Analysis of Lubeg (Syzygium lineatum (DC). Merr \& L . M . Perry) Species in Apayao. International Journal of Novel Research in Life Sciences, 3(6), 1-5.

[22]. Denny, \& Kalima, T. (2016). Keanekaragaman Tumbuhan Obat pada Hutan Rawa Gambut Punggualas, Taman Nasional Sebangau, Kalimantan Tengah. Bul. Plasma Nutfah, 22(7), 137-148.

[23]. Ito, A., Chai, H.-B., Kardono, L. B. S., Setowati, F. M., Afriastini, J. J., Riswan, S., Farnsworth N. R., Cordell G. A., Pezzuto J. M., Swanson S. M. \& Kinghorn, A. D. (2004). Saponins from the Bark of Nephelium maingayi. J. Nat. Prod, 67(2), 201-205.

[24]. Kamarulzaman, F., Ag Nuddin, J., Li Lim, K., Adam, A., Hamzah, A. S., \& Ghazali, A. R. (2017). Evaluation of Antiinflammatory, Antioxidant and Antiproliferative Activities of Quassia borneensis Noot. (Simaroubaceae) Extracts. Jurnal Sains Kesihatan Malaysia, 15(1), 33-40. https://doi.org/10.17576/jskm2017-1501-05

[25]. Atmoko, T., \& Ma'ruf, A. (2009). Uji Toksisitas dan Skrining Fitokimia Ekstrak Tumbuhan Sumber Pakan Orangutan Terhadap Larva Artemia salina L. Jurnal Penelitian Hutan Dan Konservasi Alam, VI(1), 37-46.

[26]. Shah, G., Singh, P. S., Mann, A. S., \& Shri, R. (2011). Scientific Basis for the Chemical Constituent and Therapeutic Use of Elaeocarpus Species: a Review. International Journal of Institutional Pharmacy and Life Sciences, 1(1), 267-278

[27]. Cock, I. E., \& Cheesman, M. (2019). The Potential of Plants of the Genus Syzygium (Myrtaceae) for the Prevention and Treatment of Arthritic and Autoimmune Diseases. In R. Watson \& V. Preedy (Eds.), Bioactive Food as Dietary Interventions for Arthritis and Related Inflammatory Diseases (2nd Editio, pp. 401424). https://doi.org/10.1016/B978-0-12813820-5.00023-4

[28]. Da Trindade, R., da Silva, J. K., \& Setzer, W. N. (2018). Copaifera of the Neotropics: A Review of the Phytochemistry and Pharmacology. International Journal of Molecular Sciences, 19(5). https://doi.org/10.3390/ijms19051511

[29]. Tata, H. L., Noordwijk, M. Van, Jasnari, \& Widayati, A. (2016). Domestication of Dyera polyphylla (Miq.) Steenis in Peatland Agroforestry Systems in Jambi, Indonesia. Agroforestry Systems, 90(4), 617-630. https://doi.org/10.1007/s10457-015-9837-3 